\title{
THE NATURE AND IMPORTANCE OF THE SUB-ANTARCTIC
}

\author{
by P. M. Selkirk
}

\begin{abstract}
Selkirk, P.M. 2007 (23:xi): The nature and importance of the sub-Antarctic. Papers and Proceedings of the Royal Society of Tasmania 141 ( 1): 1-6. https://doi.org/10.26749/rstpp.141.1.1 ISSN 0080-4703. Department of Biological Sciences, Macquarie University, Sydney, NSW 2109, Australia.
\end{abstract}

Sub-Antarctic land is a rare resource in world terms. It is appropriate to recognise the sub-Antarctic as a region distinct from the cool temperate zone to its north and the Antarctic zone to its south, a region with its own characteristics, and with significant intrinsic value and scientific importance. Appropriate protection from anthropogenic change and exploitation must be ensured for the sub-Antarctic. Key Words: sub-Antarctic, islands, environmental change, anthropogenic change.

\section{NATURE AND LOCATION OF THE SUB- ANTARCTIC}

From the vantage point of a plant biologist, the nature and location of the sub-Antarctic is very simple: it is the region south of the south temperate zone and north of the Antarctic zone. The sub-Antarctic is a region of much ocean and little land, a region where herbaceous flowering plants and bryophytes grow well, but where trees and shrubs are absent. It is a region where the tiny specks of land are strongly influenced by the vast ocean and where there are strong connections between marine and terrestrial ecosystems (Smith 1984, Selkirk et al. 1990, Erskine et al. 1998, Smith et al. 2001, Smith 2007).

The sub-Antarctic is a region where temperatures are low and vary little throughout the year (Jacka et al. 2004), and where there is abundant moisture. Winter days are short and summer days are long, and although all days are likely to be cloudy (Bureau of Meteorology 2007), there is ample daylight throughout the year, and plant productivity is high (Jenkin \& Ashton 1970, Jenkin 1972, Hnatiuk 1979, Smith 1984).

Sub-Antarctic islands, where tussock grasses and lush megaherbs are the tallest plants, contrast very strongly with the cool temperate region to the north, where shrubs or trees are the tallest plants around, forming the dominant vegetation layer. With their oceanic climate, the subAntarctic islands contrast equally strongly with continental Antarctica to the south, where temperatures differ markedly between summer and winter (Jacka et al. 2004), where daylight and liquid water are available to organisms in the summer but not the winter, where vegetation is dominated by mosses and lichens, growing close to the limits of their physiological tolerance. Just two species of flowering plants, Deschampsia antarctica E.Desv. and Colobanthus quitensis (Kunth)Bartl., grow in the maritime Antarctic, also at the limits of their physiological tolerance (Smith 1984, Holderegger et al. 2003, Robinson et al. 2003).

There are different conceptions of what constitutes the sub-Antarctic. Meteorologists define the sub-Antarctic one way (Pendlebury \& Barnes-Keoghan 2007), oceanographers another (Ansorge \& Lutjeharms 2007). Some confine their idea of the sub-Antarctic to the islands close to the Antarctic Polar Frontal Zone (APFZ); others include a wider range of islands and southern Patagonia. This paper, written by a terrestrial plant biologist, concentrates on the islands of the sub-Antarctic, and particularly the terrestrial biota. However, what is said about the sub-Antarctic will still be pertinent, whatever the reader's circumscription.
By many criteria, the sub-Antarctic is different from other parts of the world. "The analogous region in the northern hemisphere is commonly taken to be the vast area of tundracovered continental land bordering the Arctic Ocean to its north - northern parts of Canada, Greenland, Europe and Siberia, an environment quite different from the oceandominated sub-Antarctic (Alexandrova 1980).

It is clear that sub-Antarctic land is a rare resource in world terms, and is discussed here in terms of its importance, distinctive characteristics, intrinsic interest and value.

\section{IMPORTANCE OF THE SUB-ANTARCTIC}

The sub-Antarctic region is important as a component of world circulation systems: oceanic systems such as the Antarctic Circumpolar Current (Ansorge \& Lutjeharms 2007) and atmosphericcirculation such as the Southern Annular Mode (Pendlebury \& Barnes-Keoghan 2007).

Sub-Antarctic lands are important to the terrestrial organisms - plants, animals, micro-organisms - that live on the islands, and to the marine mammals and birds that breed there. To humans, the sub-Antarctic is important to scientists - to biologists interested in biogeography, to meteorologists recording land-based data for weather forecasting, to climatologists interested in teleconnections and in climate change, to geologists interested in tectonics and vulcanism, to oceanographers interested in the Southern Ocean - and it is important to the interested tourist visitors now in increasing numbers.

\section{DISTINCTIVE CHARACTERISTICS OF THE SUB-ANTARCTIC}

Sub-Antarctic land is entirely made up of smalloceanic islands. The islands here considered to be sub-Antarctic all lie close to the APFZ - Macquarie Island, Marion and Prince Edward islands, Crozet Archipelago to the north of the APFZ; Îles Kerguelen within the APFZ; Heard and McDonald islands and South Georgia to the south.

Sub-Antarctic islands have varying geological origins (Quilty 2007), but much in common biologically. They are breeding sites to multitudes of marine mammals and birds that depend on the Southern Ocean for their food, but depend on the sub-Antarctic islands when it comes to their reproduction. Fur seals, elephant seals, albatrosses, prions, petrels, cormorants and other marine birds all are part of the interconnections between marine and terrestrial ecosystems 
in the sub-Antarctic: they feed at sea but breed and excrete ashore, transferring nutrients as they do so (Croxall 1984, Laws 1984, Erskine et al. 1998, Smith 2007).

The islands are fringed by similar marine algae including dense vegetation of brown algae (Lüning 1990), so that the bull kelp Durvillaea antarctica (Chamisso) Hariot could be said to be the dominant plant species of the sub-Antarctic istands (Klemm \& Hallam 1988). On the islands vegetation includes tussock grasslands, mires, lakes, fellfields with cushion plants and many bryophytes (Aubert de la Rue 1964, Smith 1988, Duchêne 1989, Selkirk et al. 1990, McIntosh \& Walton 2000). Terrestrial and freshwater invertebrates found within all these vegetation rypes include cosmopolitan species as well as characteristically sub-Antarctic ones (Dartnall 2005, Dartnall et al. 2005, Chown et al. 2006, Greenslade 2006).

Indigenous biota of the sub-Antarctic islands is distinct from that of both the cool temperate and Antarctic regions. A number of species of plants and invertebrates occur on several sub-Antarctic islands but nowhere else in the world: for example, Pringlea antiscorbutica R.Br. ex Hook.f., known as Kerguelen cabbage, occurs on Îles Kerguelen, Heard and Marion islands (Telford et al. 1993); Poa kerguelensis (Hook.f.) Steud., a small tussock grass, is found on Îles Kerguelen and Heard Island (Du Puy et al. 1993); Poa cookii (Hook.f.) Hook.f., an often larger tussock grass, is found on Îles Kerguelen and Crozet, and Heard, McDonald, Marion, Prince Edward and Macquarie islands (Du Puy et al. 1993); the spider Myro kerguelensis O.P-Cambridge, 1876 occurs on Macquarie and Heard islands, Îles Kerguelen and Crozet (Greenslade 2006).

Some plants and invertebrates are endemic to particular sub-Antarctic islands: for example the small cushion plant Lyallia kerguelensis Hook.f. is endemic to Îles Kerguelen (Greene \& Walton 1975); the large cushion plant Azorella macquariensis Orchard is endemic to Macquarie Island (Orchard 1989); there are two species of orchid, Nematoceras dienemum (D.L.Jones) D.L.Jones, M.A.Clem et Molloy and $N$ sulcatum M.A.Clem et D.L.Jones, endemic to Macquarie Island (Jones 1993, Clements \& Jones 2007, Clements et al. 2007); the waterflea Daphnia gelida (Brady, 1918) is endemic to Macquarie Island (Dartnall et al. 2005); the flightless moth Pringleophaga marioni Viette, 1968 and the weevil Bothrometopus elongatus (Jeannel, 1953) are endemic to Marion Island (Barendse \& Chown 2001).

The islands are relatively small, relatively young, and have generally evolved in isolation from other landmasses (Quilty 2007). Terrestrial and freshwater organisms have reached the islands by long-distance over-ocean transport — in other words, "via airmail" (Bergstrom \& Selkirk 1987, Hennion \& Walton 1997, Greenslade et al. 1999, Dartnall et al. 2005). On-island evolution from an ancestor that arrived by "airmail" is the most likely mechanism for the development of their terrestrial and freshwater endemic species (Clements et al. 2007).

\section{INTEREST IN THE SUB-ANTARCTIC}

Eighteenth- and nineteenth-century interest in the subAntarctic was essentially economic, with the harvesting of marine mammals and birds for economic gain. Seal and penguin populations fell dramatically (Hindell \& Burton 1988, Mclntosh \& Walton 2000), in some places to extinction (Shaughnessy et al. 1988). Populations recovered to varying extents after cessation of harvesting and statutory protection of most of the animals in the early to mid-twentieth century.

In the late nineteenth century there was scientific interest in the wildtife of sub-Antarctic islands, and their natural history (Headland 1984, Bryden 1988, Duchêne 1989). By the twentieth century, sufficient scientific knowledge had accrued for some biological harvesting to be sustainably managed, for example elephant seals at South Georgia until the mid-1960s (McIntosh \& Walton 2000).

In the twentieth and twenty-first centuries scientific interest has centred on the intrinsic nature of the sub-Antarctic, and studies are working towards an understanding of geological and tectonic processes, ecological and evolutionary processes, and oceanic and upper atmospheric processes. Different islands are of interest to scientists in particular disciplines: for example Macquarie Island is particularly interesting to geologists and geophysicists studying tectonic processes (Varne et al. 2000, Goscombe \& Everard 2001, Wertz et al. 2002, Rivizzigno \& Karson 2004); McDonald Island is of particular interest for its recent active vulcanism (Quilty 1995, Kiernan \& McConnell 1999); Marion and Heard islands and Îles Kerguelen are of interest to glaciologists, geomorphologists, and biologists studying glacial retreat, its mechanisms and consequences (Scott 1990, Frenot et al. 1998, Kiernan \& McConnell 1999, Budd 2000, Ruddell 2006).

The sub-Antarctic contains indicators of widespread environmental change, hence is of interest for the observations of change and the interpretation of mechanisms of change. Records from the islands show significant warming over the past 50 years (Thost \& Allison 2006, Pendlebury $\&$ Barnes-Keoghan 2007), reduced precipitation in some regions and increased windspeed, resulting in somewhat drier conditions, especially in the mires that are significant habitats on sub-Antarctic islands. There has been substantial warming in parts of the Southern Ocean, which is likely to have a flow-around effect on its islands. Glaciers are retreating, new land is becoming ice-free and available for colonisation by organisms already nearby on the islands; there has been reduction in the extent of some species such as Sphagnum on Macquarie Island (Whinam \& Copson 2006), and an increase in others such as Acaena on Heard Island (Scott \& Bergstrom 2006). However, there is a great deal not yet known about how organisms will respond to the rapidly changing conditions. Will the colonists of newly deglaciated land all be present residents of the islands? Will the environmental changes allow the establishment of some additional species, yet to arrive by "airmail", or by human-mediated means? Will the changed environment exert different selective pressures on island biota, allowing the evolution of new, endemic species on the islands?

What about the environment itself? For instance, how will geomorphic processes be affected? Periglaciation is the geomorphic process that leads to patterned ground including stone stripes and polygons. Periglacial processes result from freeze-thaw action on unvegetated ground. If temperatures rise so that fewer freeze-thaw cycles occur, periglacial processes may become much more limited in extent, to become restricted to progressively higher parts of the islands where freeze-thaw cycles continue and, ultimately, be inactive in the sub-Antarctic.

On Macquarie Island, peatslides around the steep coastal slopes are triggered by heavy rainfall events. When rain saturates the peat, it becomes unstable and fails when the combined load of vegetation, peat and water becomes too 
great for the slope to support (Selkirk 1996). If precipitation decreases and evaporation increases, the incidence of subAntarctic peatslides may diminish.

Clearly the sub-Antarctic is a particularly interesting place, one that is interesting to many people, a place that has the capacity to help us understand a number of fundamental processes.

\section{VALUE OF THE SUB-ANTARCTIC}

The intrinsic value of the sub-Antarctic islands has formally been recognised in World Heritage listing for Macquarie Island, Heard Island and the McDonald Islands, and the New Zealand shelf islands, and in the tentative World Heritage listing of Marion and Prince Edward islands.

In the past, the sub-Antarctic had commercial value for its exploitable biota - the myriad seals and penguins whose skins clothed many people, and whose oil lit many houses. Now there is monetary value in tourism, and potentially in future for other purposes, such as the development of sub-Antarctic plants as vegetable or horticultural crops (Dawson 1998), or sub-Antarctic microbiota as sources for biotechnology developments.

The risk of damage to the sub-Antarctic should not be overlooked. There is risk of damage to sub-Antarctic islands from alien plants, specifically those that become invasive. Many such plants have arrived on sub-Antarctic islands as hitchhikers on humans and their equipment, from soon after the islands were discovered, through the era of seal and penguin and whale exploitation, through settlement and farming practices, to the present era of scientific investigation and tourism (Whinam et al. 2004, Frenot et al. 2005, Convey et al. 2006, Bergstrom \& Selkirk 2007). Similarly, alien animals that become feral pose threats to sub-Antarctic environments. Some, such as mice and rats, travelled on ships and went ashore uninvited; others, such as cats, rabbits and reindeer, were imported for a purpose at a time when the threats they would later pose were not appreciated (Leader-Williams 1988, Convey et al. 2006). Recovery programs have achieved the eradication of cats from Marion Island (Bester et al. 2002), of weka and cats from Macquarie Island (Copson 1995, 2003), of rabbits and rats from Île Saint Paul and from three small islands in the Îles Kerguelen (Lebouvier \& Frenot 2007), and of rats from Campbell Island (McClelland \& Tyree 2004, Shepherd 2007). Quarantine measures aim to prevent further introductions (Copson \& Whinam 2001, Whinam et al. 2006), and management practices are in place for the control of some of the alien species now present (Copson \& Whinam 2001, Courchamp et al. 2003, Cooke et al. 2004). On Macquarie Island, however, management of the feral rabbit population has become ineffective, with deleterious consequences for bird populations and vegetation (Considine 2007, Parks and Wildlife Service 2007). A plan for the eradication of rabbits and rodents has been developed (Parks and Wildlife Service 2007), funding from the Australian and Tasmanian governments has been approved, and the plan is expected to be implemented over the years 2007 to 2012 .

Other threats of damage to sub-Antarctic islands come from anthropogenic pollution danage including fuel leaks and waste dumping (Stark et al. 2003). Hydrocarbon spills are considered to be more damaging in cold than in warmer climates, and ecosystem recovery slower (Snape et al. in press). Surveys and toxicity testing have shown the need for remediation in some locations (Stark et al. 2003, Schafer $e t$ al. in press, Rayner et al. in press). Considerable quantities of derelict building materials have been removed from Heard Island during several clean-up operations (Stark et al. 2003, Hull 2002) and plans are in train for remediation at sites on Macquarie Island (Raymond et al. 2005). The oil spill associated with the 1987 foundering of M.V. Nella Dan killed invertebrates and adversely affected the littoral and sub-littoral environment over several kilometres of Macquarie Island's shoreline for more than a year (Pople et al. 1990). Marine plastic rubbish, often dumped thousands of kilometres away, damages birds and seals both at sea and on beaches when washed ashore (Slip \& Burton 1991).

There is potential for change in the sub-Antarctic. Climate change, including rising temperatures and falling precipitation, and resultant environmental change including retreating glaciers, have been considered above. These changes in the physical environment will be associated with biological changes; there is the potential for additional biota to arrive naturally and to become established, independent of human agency; and there is the capacity for new biota to evolve.

It is clear that all change is not a bad thing, to be resisted: the world has been a changing place throughout its existence and continues to change. The sub-Antarctic is no exception - Macquarie Island continues to rise as tectonic plates move (Adamson et al. 1996), McDonald Island continues to expand following recent volcanic eruptions (Australian Antarctic Division 2005).

It is appropriate to ponder, with better knowledge and understanding than in the past, whether the sub-Antarctic is adequately protected from deleterious exploitation, and indeed from deleterious anthropogenic change, of any nature.

\section{CONCLUSION}

I believe that the sub-Antarctic, however defined, must be recognised as a region in its own right, distinct from the Antarctic region to its south and from the cool temperate region to its north. It is time to move away from the longstanding tendency for the sub-Antarctic to be regarded as "not the real Antarctic", or "less than the Antarctic".

The characteristics, intrinsic value and scientific importance of the sub-Antarctic must be recognised, and appropriate protection from deleterious anthropogenic change and exploitation ensured. Humans, as custodians of the planet, must recognise and value the unique qualities of, and must care for all parts of, the Earth, including the sub-Antarctic.

\section{ACKNOWLEDGEMENTS}

I thank the organisers of the International Forum on the SubAntarctic, held in Hobart in July 2006, for bringing together this group of scientists and managers with sub-Antarctic interests, expertise and passions. I thank the Australian Antarctic Division, Antarctica New Zealand, l'Institut polaire français Paul-Émile Victor, Macquarie University and my extended family for supporting and facilitating my research in southern high latitudes, conducted over 25 years. 


\section{REFERENCES}

Adamson, D.A., Selkirk, P.M., Price, D., Ward, N. \& Selkirk, J.M. 1996: Pleistocene uplift and palaeoenvironments of Macquarie Island: evidence from palaeobeaches and sedimentary deposits. Papers and Proceedings of the Royal Society of Tasmania 130: 25-32.

Aleksandrova, V.D. 1980: The Arctic and Antarctic: Their Division into Geobotanical Areas. Cambridge University Press, Cambridge: 247 pp. [first published in Russian 1977, translated by D. Löve].

Ansorge, I. \& Lutjeharms, J.R.E. 2007: The influence of the Antarctic Circumpolar Current on the oceanographic setting of the Prince Edward Islands. Papers and Proceedings of the Royal Society of Tasmania 141(1): 59-66.

Aubert de la Rue, E. 1964: Observations sur les caractères et la repartition de la vegetation des Îles Kerguelen. Comité National Français des Recherches Antartiques, Biologie 1: $1-60$.

Australian Antarctic Division 2005: Heard Island and McDonald Islands Marine Reserve Management Plan. Austratian Government: 198 pp.

Barendse, J. \& Chown, S.L. 2001: Abundance and seasonality of mid-altitude fellfield arthropods from Marion Island. Polar Biology 24: 73-82.

Bergstrom, D.M. \& Selkirk, P.M. 1987: Reproduction and dispersal of mosses on Macquarie Island. Symposia Biologica Hungarica 35: 247-257.

Bergstrom, D.M. \& Selkirk, P.M. 2007: Human impacts on subAntarctic terrestrial environments. Papers and Proceedings of the Royal Society of Tasmania 141(1): 159-168

Bester, M.N., Bloomer, J.P., Van Aarde, R.J., Erasmus, B.H., Van Rensburg, P.J.J., Skinner, J.D., Howell, P.G. \& Naude, T.W. 2002: A review of the successful eradication of feral cats from sub-Antarctic Marion Island, Southern Indian Ocean. South African Journal of Wildlife Research 32: $65-73$.

Bryden, M. 1988: Macquarie Island - a wonder spot of the world. Papers and Proceedings of the Royal Society of Tasmania 122(1): 1-7.

Budd, G.M. 2000: Changes in Heard Island glaciers, king penguins and fur seals since 1947. Papers and Proceedings of the Royal Society of Tasmania 133(2): 47-60.

Bureau of Meteorology 2007: Climatic averages for Macquarie Island 1948-2004, Australian Government, Bureau of Meteorology. Available at: http://www.bom.gov.au/ climate/averages/tables/cw_300004.shtml (accessed 19 January 2007).

Chown, S.L., Greenslade, P. \& Marshall, D.J. 2006: Terrestrial invertebrates of Heard Island. In Green, K. \& Woehler, E. (eds): Heard Island: Southem Ocean Sentinel. Surrey Beatty \& Sons, Chipping Norton: 91-104.

Clements, M.A. \& Jones, D.L. 2007: A new species of Nematoceras and characterisation of $N$. dienemum (Orchidaceae), both from subantarctic Macquarie Island. Telopea 11(4): 405-411.

Clements, M.A., Mackenzie, A.M., Copson, G.R., Molloy, B.P.J., Carmichael, N., Skotnicki, M.L. \& Selkirk, P.M., 2007: Biology and molecular phylogenetics of Nematoceras sulcatum, a second endemic orchid species from subantarctic Macquarie Island. Polar Biology 30: $859-869$.

Considine, M.-L. 2007: Politics adds to Macquarie Island's pest problem. ECOS (CSIRO) 136: 20-21.

Convey, P., Frenot, Y., Gremmen, N. \& Bergstrom, D.M. 2006: Biological invasions. In Bergstrom, D.M., Convey, P. \& Huiskes, A.H.L. (eds): Trends in Antarctic Terrestrial and Limnetic Ecosystems. Springer, Dortrecht: 193-220.

Cooke, B.D., Chapuis, J.-L., Magnet, V., Lucas, A. \& Kovaliski, J. 2004: Potential use of myxoma virus and rabbit haemorrhagic disease virus to control feral rabbits in the
Kerguelen Archipelago. Wildlife Research 31: 415-420.

Copson, G.R. 1995: An integrated vertebrate pest strategy for subantarctic Macquarie Island. In Proceedings of the $10^{\text {th }}$ Vertebrate Pest Control Conference, Hobart, May 1995.

Copson, G.R. 2003: Integrated Vertebrate Pest Management on Subantarctic Macquarie Island 1997-2002. Final Report to the Natural Heritage Trust. Department of Primary Industries, Water and Environment, Hobart: 37 pp.

Copson, G. \& Whinam, J. 2001: Review of ecological restoration programs on sub-Antarctic Macquarie Island: pest management progress and future directions. Ecological Management and Restoration 2(2): 129-138.

Courchamp, F., Chapuis, J.-L. \& Pascal, M. 2003: Mammal invaders on islands: impact, control and control impact. Biological Reviews 78: 347-383

Croxall, J.P. 1984: Seabirds. In Laws, R.M. (ed.): Antarctic Ecology. Academic Press, London: 533-619.

Dartnall, H.J.G., Hollwedel, W. \& de Paggi, J.C. 2005: The freshwater fauna of Macquarie Island, including a redescription of the endemic water-flea Daphnia gelida (Brady) (Anomopoda:Crustacea). Polar Biology 28: 922-939.

Dartnall, H.J.G. 2005: Freshwater invertebrates of subantarctic South Georgia. Journal of Natural History 39(37): 3321-3342.

Dawson, I. 1998: New Salad \& Vegetable Crops from Australia's sub-Antarctic Islands. Report for Rural Industries Research and Development Corporation, RIRDC Publication number 98/145: $35 \mathrm{pp}$.

Duchêne, J.C. 1989: Kerguelen Recherches au bout du monde. Territoires des Terres Australes et Antarctiques Françaises, Mission de Recherche: 360 pp.

Du Puy, D.J., Telford, I.R.H. \& Edgar, E. 1993: Poaceae. Flora of Australia 50: 456-511.

Erskine, P.D., Bergstrom, D.M., Schmidt, S., Stewart, G.R., Tweedie, C.E. \& Shaw, J.D. 1998: Subantarctic Macquarie Island - a model ecosystem for studying animal-derived nitrogen sources using $\mathrm{N}^{15}$ natural abundance. Oecologia 117(1-2): 187-193.

Frenot, Y., Gloaguen, J.C., Cannavacciuolo, M. \& Bellido, A. 1998: Primary succession on glacier forelands in the subantarctic Kerguelen Islands. Journal of Vegetation Science 9(1): 75-84.

Frenot, Y., Chown, S., Whinam, J.P., Sellkirk, P.M., Convey; P., Skotnicki, M.L. \& Bergstrom, D.M. 2005: Biological invasions in the Antarctic: extent, impacts and implications. Biological Reviews 80: 45-72.

Goscombe, B.D. \& Everard, J.L. 2001: Tectonic evolution of Macquarie Island: extensional structures and block rotations in oceanic crust. Journal of Structural Geology 23: 639-673.

Greene, S.W. \& Walton, D.W.H. 1975: An annotated checklist of the sub-Antarctic vascular flora. Polar Record 17(110): 473-484.

Greenslade, P. 2006: The Invertebrates of Macquarie Island. Australian Antarctic Division, Kingston: 344 pp.

Greenslade, P., Farrow, R.A. \& Smith, J.M.B. 1999: Long distance migration of insects to a subantarctic island. Joumal of Biogeography 26(6): 1161-1167.

Headland, R. 1984: The Island of South Georgid. Cambridge University Press, Cambridge: $293 \mathrm{pp}$.

Hennion, F. \& Walton, D.W.H. 1997: Ecology and seed morphology of endemic species from Kerguelen phytogeographic zone. Polar Biology 18(4): 229-235.

Hindell, M.A. \& Burton, H.R. 1988: The history of the elephant seal industry at Macquarie Island and an estimate of the pre-sealing numbers. Papers and Proceedings of the Royal Society of Tasmania 122(1): 159-176.

Hnatiuk, R.J., 1979: The growth of tussock grasses on an equatorial high mountain and on two sub-Antarctic islands. In Troll, 
C. \& Lauer, W. (eds): Geoecological Relations Between the Southern Temperate Zone and the Tropical Mountains: $159-190$.

Holderegger, R., Stehlik, I., Smith, R.I.L. \& Abbott, R.J. 2003 : Populations of Antarctic hairgrass (Deschampsia antarctica) show low genetic diversity. Arctic, Antarctic and Alpine Research 35(2): 214-217.

Hull, B. 2002: HIMI Ordinance Permit No 00/24, Report, Clean-up of old ANARE station, Atlas Cove, Heard Island, 2000/01. Unpublished report, Australian Antarctic Division, Kingston, Tasmania. 11 pp.

Jacka, T.H., Budd, W.H. \& Holder, A. 2004: A further assessmen of surface temperature changes at stations in the Antarctic and Southern Ocean, 1949-2002. Annals of Glaciology 39: $331-338$.

Jenkin, J.F. 1972: Studies on plant growth in a subantarctic environment. Unpublished PhD thesis, University of Melbourne, Melbourne.

Jenkin, J.F. \& Ashton, D.H. 1970: Productivity studies on Macquarie Island vegetation. In Holdgate, M.W. (ed.): Antarctic Ecology. Academic Press, New York: 2: 851-863.

Jones, D.L. 1993. Corybas dienema. Flora of Australia 50: 572.

Kiernan, K. \& McConnell, A. 1999: Geomorphology of the SubAntarctic Australian Territory of Heard Island-McDonald Island. Australian Geographer 30(2): 159-195.

Klemm, M.F. \& Hallam, N.D. 1988: Standing crop of Durvillaea antarctica (Chamisso) Hariot (Phaeophyta) on the Australian sub-Antarctic Macquarie and Heard Islands. Phycologia 27(4): 505-509.

Laws, R.M. 1984: Seals In Laws, R.M. (ed.) Antarctic Ecology Academic Press, London: 621-716.

Leader-Williams, N. 1988: Reindeer on South Georgia: The Ecology of an Introduced Population. Cambridge University Press, Cambridge: 319 pp.

Lebouvier, M. \& Frenot, Y. 2007: Conservation and management in the French sub-Antarctic islands and surrounding seas. Papers and Proceedings of the Royal Society of Tasmania 141: $23-28$

Lüning, K. 1990: Seaweeds Their Environment, Biogeography and Ecophysiology. John Wiley and Sons, New York: 527 pp.

McClelland, P. \& Tyree, P. 2002: Eratication: the clearance of Campbell Island. New Zealand Geographic 58: 86-94

McIntosh, E. \& Walton, D.W.H. 2000: Environmental Management Plan for South Georgia. Published by British Antarctic Survey on behalf of Government of South Georgia and the South Sandwich 1slands: 105 pp.

Orchard, A.E. 1989: Azorella Lamarck (Hydrocotylaceae) on Heard and Macquarie Island. Muelleria 7: 15-20.

Parks and Wildlife Service \& Biodiversity Conservation Branch 2007: Plan for the Eradication of Rabbits and Rodents on Subantarctic Macquarie Island. Department of Tourism, Arts and the Environment \& Department of Primary Industries and Water, Hobart, Tasmania: $30 \mathrm{pp}$.

Pople, A., Simpson, R.D. \& Cairns, S.C. 1990: An incident of Southern Ocean oil pollution: effects of a spillage of diesel fuel on the rocky shore of Macquarie Island (subAntarctic). Australian Journal of Marine and Freshwater Research 41(5): 603-620.

Pendlebury, S.F. \& Barnes-Keoghan, I.P. 2007: Climate and climate change in the sub-Antarctic. Papers and Proceedings of the Royal Society of Tasmania 141(1): 67-82.

Quilty, P.G. 1995: Heard Island: offshore McDonald Islands. Bulletin of Volcanic Eruptions 32: 32-33 \& 127-128.

Quilty, P.G. 2007: Origin and evolution of the sub-Antarctic islands: the foundation. Papers and Proceedings of the Royal Society of Tasmania 141(1): 35-58

Raymond, T.C., Snape, I., Rayner, J.L. \& Harvey, P.M. 2005: Field Work Plan 2006/07: Remediation of the Main Power House and Fuel Farm at Macquarie Island Station. Australian Antarctic Division, Kingston: 26 PP.
Rayner, J.L., Snape, I., Walworth, J.L., Harvey, P.M. \& Ferguson, S.H. 2007: Petroleum-hydrocarbon contamination and remediation by microbioventing at subAntarctic Macquarie Island. Cold Regions Science and Technology 48: 139-153.

Rivizzigno, P. A. \& Karson, J. A. 2004: Structural expression of oblique seafloor spreading in the Macquarie Island ophiolite, Southern Ocean. Geology 32(2): 125-128.

Robinson, S.A., Wasley, J. \& Tobin, A.K. 2003: Living on the edge - plants and global change in continental and maritime Antarctica. Global Change Biology 9(12): 1681-1717.

Ruddell, A. 2006: An inventory of present glaciers on Heard Island and their historical variation. In: Green, K. \& Woehler, E. (eds): Heard Island: Southern Ocean Sentinel. Surrey Beatty \& Sons, Chipping Norton: 28-51.

Schafer, A.N., Snape, I. \& Siciliano, S.D. In press: Soil biogeochemical toxicity endpoints for sub-Antarctic Islands contaminated with petroleum hydrocarbons. Environmental Toxicology of Chemistry.

Scott, J.J. 1990: Changes in vegetation on Heard Island 1947-1987. In Kerry, K. \& Hempel, G. (eds): Antarctic Ecosystems, Ecological Change and Conservation. Springer Verlag, Berlin: 61-76.

Scott, J.J. \& Bergstrom, D.M. 2006: Vegetation of Heard Island and the McDonald Islands. In Green, K. \& Woehler, E. (eds) Heard Island: Southern Ocean Sentinel. Surrey Beatty \& Sons, Chipping Norton: 69-104.

Selkirk, J.M. 1996: Peat slides on subantarctic Macquarie Island. Zeitschrift für Geomorphologie 105: 61-72.

Selkirk, P.M., Seppelt, R.D. \& Selkirk, D.R. 1990: Subantartic Macquarie Island Environment and Biology. Cambridge University Press, Cambridge: $285 \mathrm{pp}$.

Shaughnessy, P.D., Shaughnessy, G.L. \& Fletcher, L. 1988: Recovery of the fur seal population at Macquarie Island. Papers and Proceedings of the Royal Society of Tasmania 122(1): 177-187.

Shepherd, I. 2007: The long journey home for Campbell Island Teal. ECOS (CSIRO) 134: 8-11.

Slip, D.J. \& Burton, H.R. 1991: Accumulation of fishing debris, plastic litter, and other artefacts, on Heard and Macquarie Islands in the Southern Ocean. Environmental Conservation 18(3): 249-254.

Smith, R.I.L. 1984: Terrestrial plant biology of the sub-Antarctic and Antarctic. In Laws, R.M. (ed.): Antarctic Ecology. Academic Press, London: 1: 61-162.

Smith, V.R. 1988: Production and nutrient dynamics of plant communities on a sub-Antarctic island. Polar Biology 8 : 255-269.

Smith, V.R. 2007: Terrestrial ecological processes and problems on sub-Antarctic islands. Papers and Proceedings of the Royal Society of Tasmania 141(1): 99-110.

Smith, V.R, Steenkamp, M. and Gremmen, N.J.M. 2001 Terrestrial habitats on sub-Antarctic Marion Island: their vegetation, edaphic attributes, distribution and response to climate change. South African Journal of Botany 67(4): 641-654.

Snape, I., Acomb, L., Barnes, D.L., Bainbridge, S., Eno, R., Filler, D.M., Plato, N., Poland, J.S., Raymond, T.C., Rayner, J.L., Riddle, M.J., Rike, A.G., Rutter, A., Schafer, A.N., Siciliano, S.D. \& Walworth, J.L. (in press): Contamination, regulation and remediation: an introduction to bioremediation of petroleum hydrocarbons in cold regions. In: Filler, D.M., Barnes, D.L. \& Snape, I. (eds): Bioremediation of Petroleum Hydrocarbons in Cold Regions - A Handbook. Cambridge University Press, Cambridge.

Stark, S.C., Gardner, D., Snape, I. \& McIvor, E. 2003: Assessment of contamination by heavy metals and petroleum hydrocarbons at Atlas Cove Station, Heard Island. Polar Record 39(211): 397-414. 
Telford, I.R.H., Orchard, A.E. \& Du Puy, D.J. 1993: Brassicaceae. Flora of Australia 50: 170-178.

Thost, D. \& Allison, I. 2006: The climate of Heard Island. In Green, K. \& Woehler, E. (eds): Heard Island: Southern Ocean Sentinel. Surrey Beatty \& Sons, Chipping Norton: 52-68.

Varne, R., Brown, A.V. \& Falloon, T. 2000: Macquarie Island: its geology, structural history, and the timing and tectonic setting of its N-MORB to E-MORB magmarism. In Dilek, Y., Moores, E., Elthon, D. \& Nicolas, A. (eds): Geological Society of America Special Paper 349: Ophiolites and Oceanic Crust, new insights from field studies and the Ocean Drilling Program. pp 301-320.

Wertz, K., Snow, J.E., Hellebrand, E., von der Handt, A. \& Mosher, S. 2002: Depleted Peridotites of Macquarie Island, an Uplifted Section of in-situ Oceanic Crust.
American Geophysical Union, Fall Meeting 2002, abstract \#V52A-1284.

Whinam, J., Chilcott, N. \& Bergstrom D.M. 2004: Subantarctic hitchhikers: Expeditioners as vectors for the introduction of alien organisms. Biological Conservation 121: 207-219.

Whinam, J. \& Copson, G. 2006: Sphagnum moss: an indicator of climate change in the sub-Antarctic. Polar Record 42: 43-49.

Whinam, J., Copson, G. \& Chapuis, J.-L. 2006: Subantarctic terrestrial conservation and management. In Bergstrom, D.M., Convey, P. \& Huiskes, A.H.L. (eds): Trends in Antarctic Terrestrial and Limnetic Ecosystems. Springer, Dordrecht: 297-316.

(accepted 30 July 2007) 